\title{
التشبيه المرسل ومضمون معانيها في السورة الرّعد و ابراهيم
}

\section{Wirna Moonti, Nurul 'Aini Pakaya, Cutri A. Tjalau, Sastra Arab, Fakultas Ilmu Budaya - UMG}

$$
\text { تجريد البحث }
$$

هذا البحث يتكلم عن " التشبيه المرسل ومضمون معانيها في السورة الرّعد و ابراهيم ". أما بالنسبة

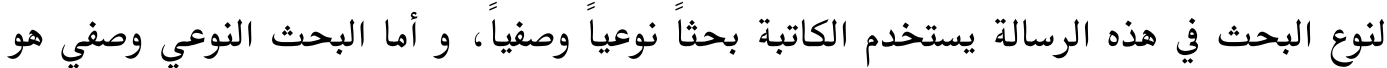

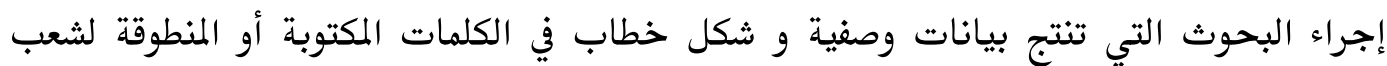

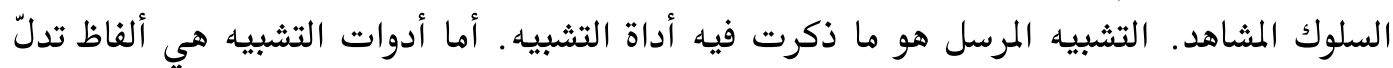

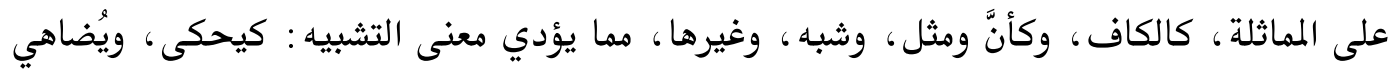

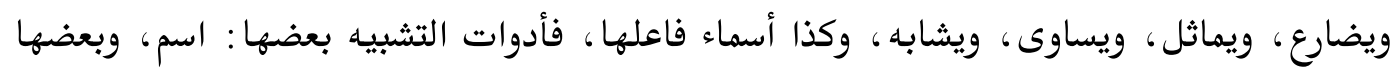

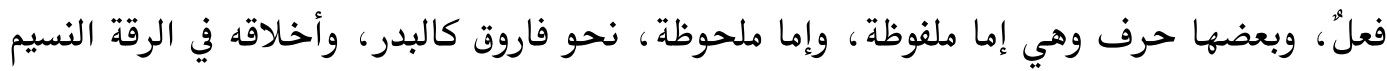

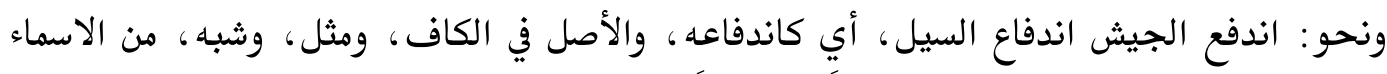
المضافة لما بعدها ان يليها المشبه به لفظاً أو تقديراً.

$$
\text { أ. الكلمات الرئيسية: التشبيه، المرسل، سورة الرعد و إبراهيم }
$$

القرآن هو كلام الله المنزّل، المنزّل على النبي محمد صلى اللّ عليه وسلّم بوسطةجبريل عليه السلام المكتوب في المصاحف، المنقول بالتواتر، المتعبد بتلاوتة المبدوع بسورة الفاتحة المخاتتم بسورة الناس ا. ولأن القرآن نزل بلغة العرب، فإنّ من أوجه تأويل ما كان علمه عند أهل اللسان الذى نزل به القرآن، وذلك علم تأويل عريته و إعرابه, لايوصل إلى علم ذلك إلا من فبلهمب. فاللغة العربي هي لغة القرآن الكريم والحديث. والمسلم الذى يريد أن يستنبط لتعليم الإسلام من مصدره

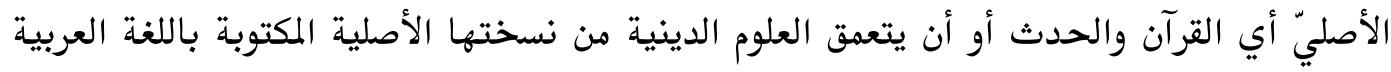

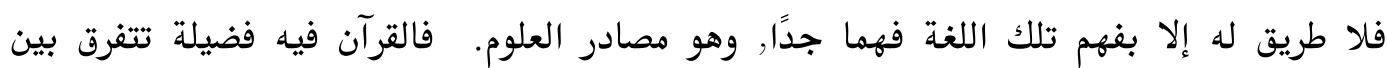

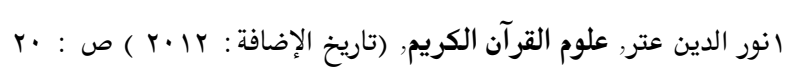

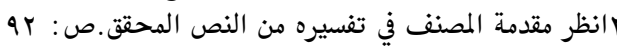

\section{'A Jamiy, Jurnal Bahasa dan Sastra Arab Volume 07, No. 1,Juni 2018}


الكتب الأخرى وهي وجود كلامه الفصاحه والبلاغة, فكان أسلوبه وتركيبه لم يكون سواه, وهو مصدر جميع العلوم, وفي القرآن مظهر غريب لإعجازه وخصوصا في أسلوبه.

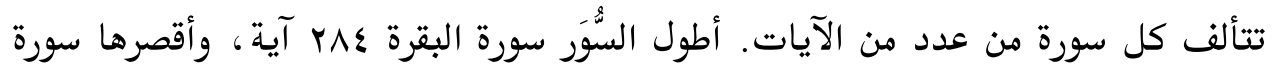

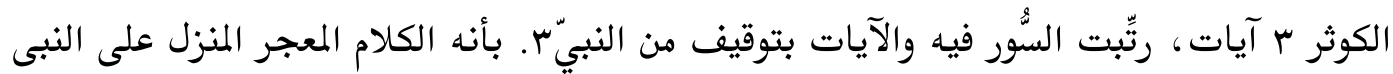
صلى الله عليه وسلم, المكتوب في المصاحف, المنقول بالتواتر، المتعبد بتلاوته ع. فالبلاغة من الدراسة الغوية، وهي تأدية المعني الجليل واضحا بعبارة صحيحة فصيحةه. قال الله تعالى ويوم نبعث في

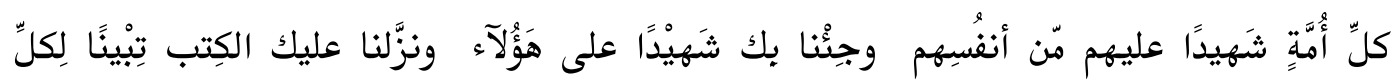
شَيٌْ وهدًى ورحمةً وبشرَى لِلْمسلمينجا. وسورة الرعد هي إحدى سور القرآن المدنية وعدد آياتها ثلاث وأربعون آية, و تقع في السورة الرقم با و له ثمانمائة وخمس وستون عدد الكلمات و ·هـب عدد الحروف. وهي أول سورة في الجزء الثالثة عشرة. وقد سميت السورة الرعد لتلك الظاهرة الكونية.وذا الرعد جمع النقيضين فهو على كونه مخيفا في ظاهره إلا أنه فيه الخير كله من الماء الذي ينزل من السحاب الذي يحمل الماء والصواعق وفي الماء الإحياء وفي الصواعق الإفناء و لهلاك وقد قال القائل:جمع النقيضين من أسرار قدرته هذا السحاب به نار. و سورة الرعد هي إحدى سور القرآن المكية وعدد آياتها به آية,

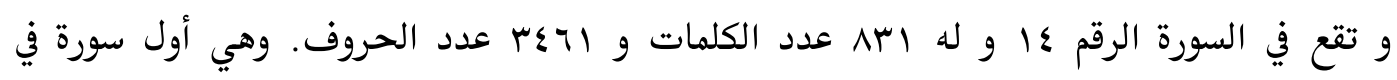
الجزء الثالثة عشرةV.

ولا يستوحشوا منهم، أو يأنفوا الانقياد لهم، إذا كانوا من قوم غير قومهم، ومن أمة غير أمتهم. والمراد بلسان قومه، جذسهم، ولغتهم التي يتعاملون بها، إذ كان اللسان هو أداة اللغة وترجمانها. وإذ كانت اللغة هى التي تكشف عن وجه الإنسان، وعن الأمة التي ينتمى إليها. إشارة إلى الحكمة التي من أجلها جاء الرسول إلى كل أمة، منها، وبلسانها، حتى يفهموا عنه. فببيانه ينكشف لهم الطريق إلى اللّ، وبغير هذا البيان يظل الطريق بينهم وبين الرسول مسدودا. إشارة أخرى إلى أن هذا البيان الذي يبيّنه الرسول لقومه، ليس فيه قهر لهم، أو إلجاء واضطرار

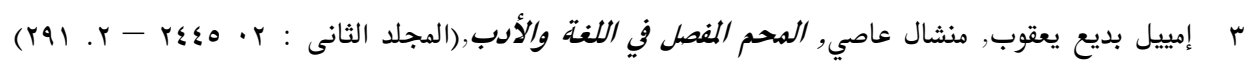

$$
\begin{aligned}
& \text { qVV-9V7 } \\
& \text { §محم عبد العظيم الزرقاني, مناهل العرفان في عاوم الُّرآن, المجلد لاؤل, (دار الفك)ر, ص : } 19
\end{aligned}
$$

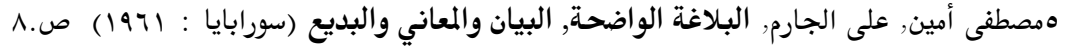

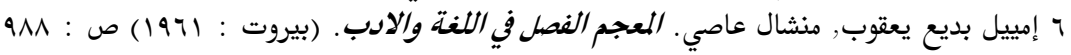


إلى الإيمان باللّ. ذلك أن الإيمان بالله، هو بيد الله، فمن شاء اللّ له الإيمان، آمن، ومن لم يشأ له

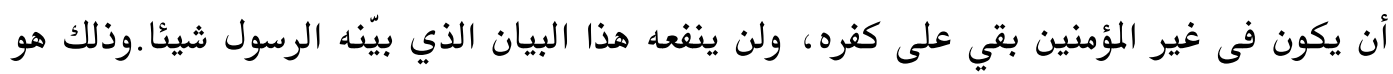

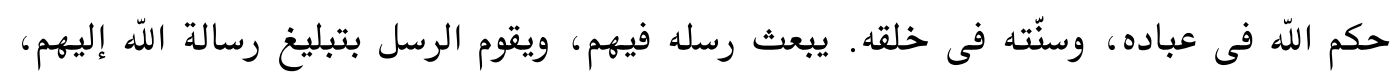

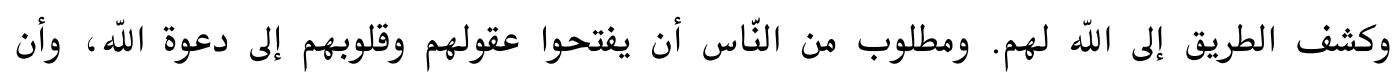

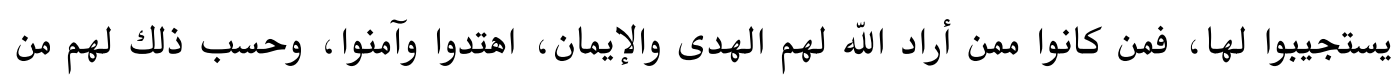

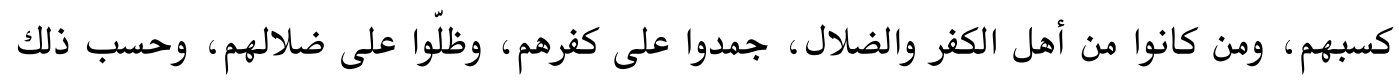

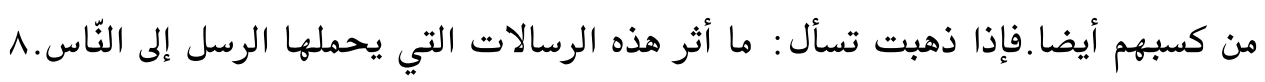

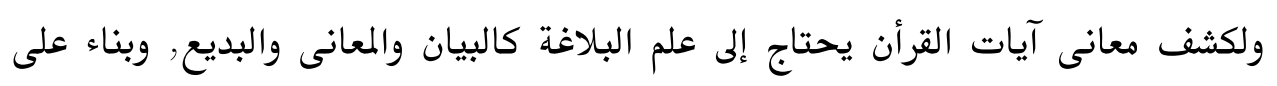

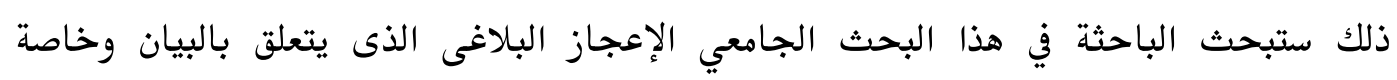

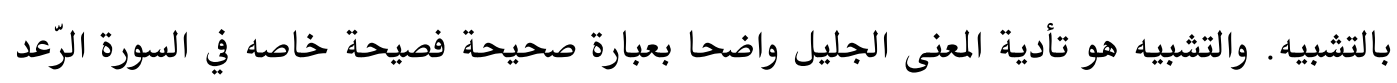

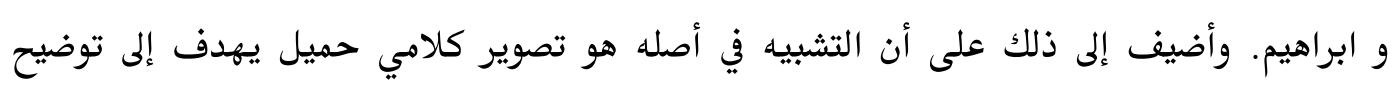

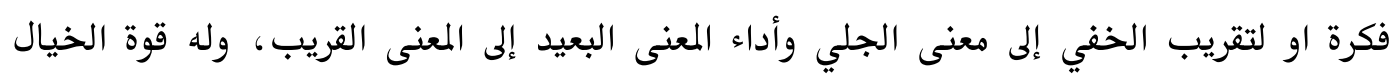

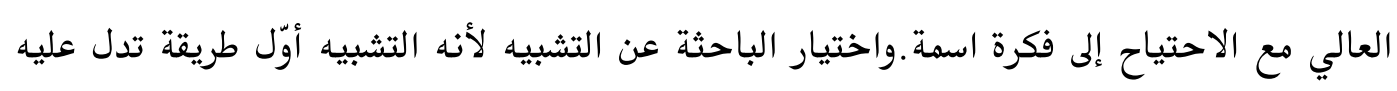

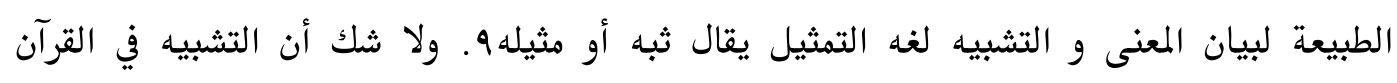

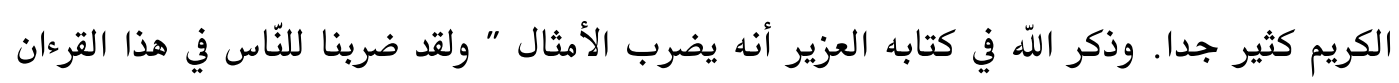

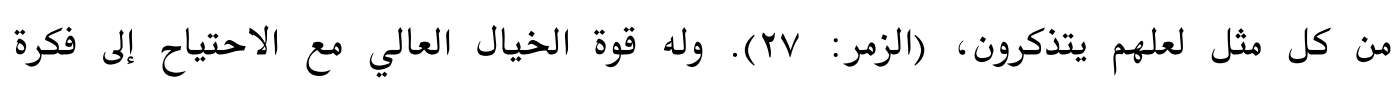

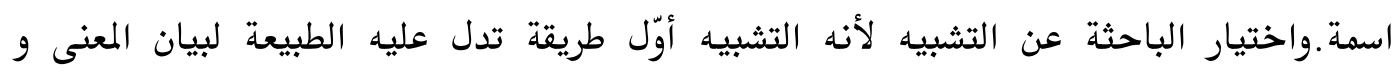

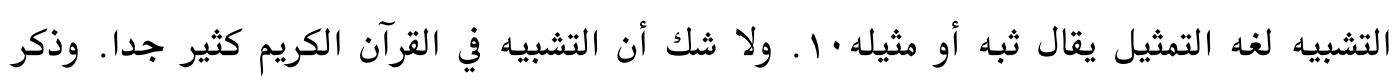

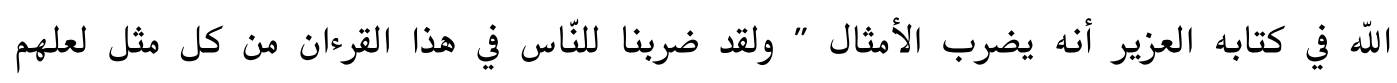

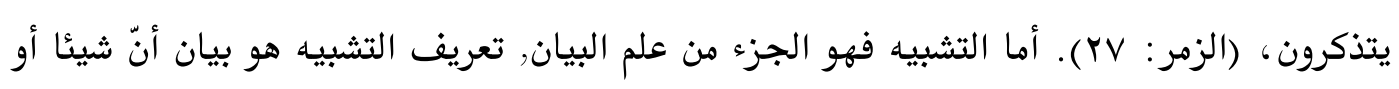

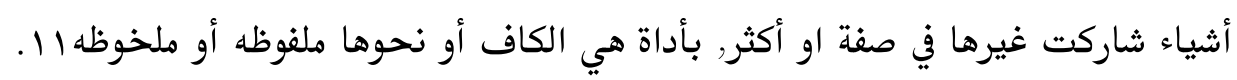

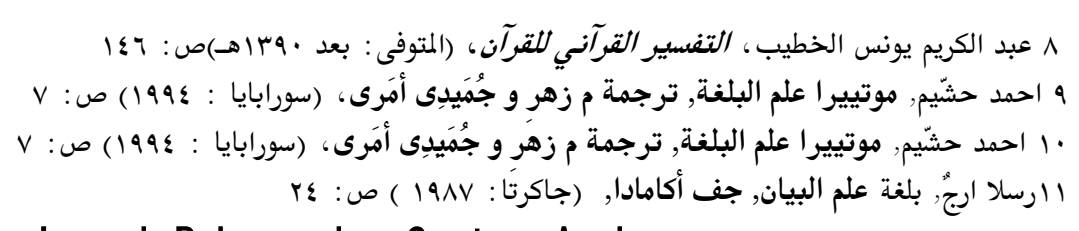

\section{'A Jamiy, Jurnal Bahasa dan Sastra Arab}

Volume 07, No. 1, Juni 2018 
التشبيه المرسل هو ما ذكرت فيه أداة التشبيه. أما أدوات التشبيه هي ألفاظ تدلّ على

المماثلة، كالكاف، وكأنَّ ومثل، وشبه، وغيرها، مما يؤدي معنى التشبيه : كيحكى، ويُضاهي ويضارع، ويماثل، ويساوى، ويشابه، وكذا أسماء فاعلها، فأدوات التشبيه بعضها: اسم، وبعضها فعلٌ، وبعضها حرف وهي إما ملفوظة، وإما ملحوظة، نحو فاروق كالبدر، وأخلاقه في الرقة النسيم ونحو: اندفع الجيش اندفاع السيل، أي كاندفاعه، والأصل في الكاف، ومثل، وشبه، من الاسماء

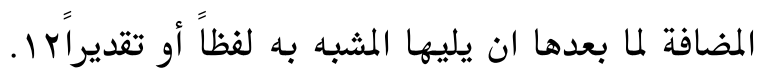

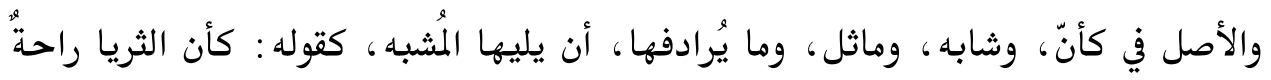

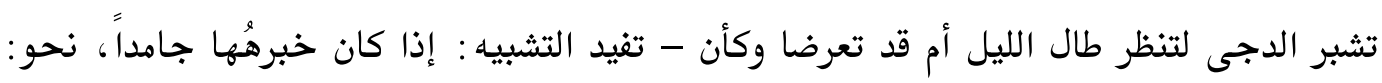
كأن البحر مرآة صافية. وقد تفيد الشك: إذا كان خبرهُها مشتقاً، نحو: كأنّك فاهم - وكقوله :

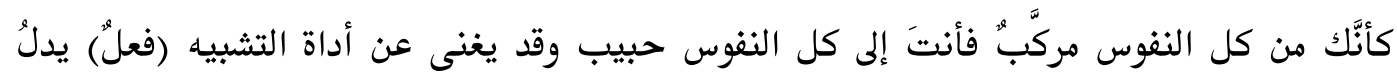
على حال التشبيه، ولا يعتبر أداة. وفي المعنى الآخر أن أدوات التشبيه فهي ألفاظ تدل على ملى

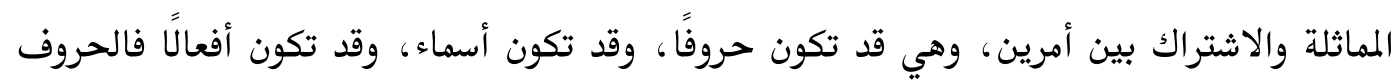
تتمثل في الكاف، أما الكاف فهي الأصل لبساطتها، وتفيد المشابهة في جميع استعمالاتها، والأصل فيها أن يليها المشبه به.برا ( الغرض من التّبييه والفائدة منه، هي الإيضاح والبيان (في التشبيه غير المقلوب) ويرجع ذلك الغرض إلى المشبه - وهو - إمّا. (أ) بيان حاله - وذلك حينما يكون المشبه مبهماً غير معروف الصفة ، التي يُراد إثباتها له قبل التشبيه، فيفيده التشبيه الوصف، ويُوضّحه المشبه به، نحو شجر النارنج كشجر البرتقال 
- وكقول الشاعر: إذا قامت لحاجتها تثنّت كأن عظامها من خيزٌران (شبه عظامها بالخزران بياناً لما فيها من اللين).

(ب) أو بيانُ إمكان حاله - وذلك حين يُسند إليه أمر مستغرب لا تزول غرابته إلا بذكر شبيه

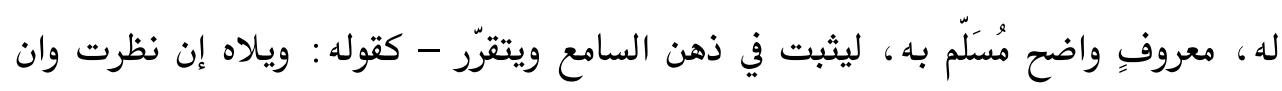
هي أعرضت وقع السِّهام ونزعُهنَّ أليم (شبّه نظرها: بوقع السهام، وشبه إعراضها بنزعها : بياناً لإمكان إيلامها بهما جميعاً)

(ج) او بيان مقدار حال المشبه في القوّة والضّعف، وذلك إذا كان المشبه معلوماً، معروف الصفة التي يُراد اثباتها له معرفة اجمالية قبل التشبيه بحيث يراد من ذلك التشبيه بيان مقدار نصيب المشبه من هذه الصفة وذلك بأن يعمدَ المتكلَّ لأن يبين للسامع ما يعنيه من هذا المقدار - كقوله : كأن مشيتها من بيت جارتها مر الحساب لا ريث ولا عجلٌ وكتشبيه: الماء بالثلج، في شدة البرودة - وكقوله : فيها اثنتان واربعون حلُوبةً سوداً كخافية الغراب الأسحم (شبه النياق السود، بخافية الغراب، بياناً لمقدار سوادها، فالسواد صفة مشتركة بين الطرفين)

أو تقرير حال المشبه، وتمكينه في ذهن السامع، بابرازها فيما هي فيه أظهر، كما إذا كان

ما أسند إلى المشبه يحتاج إلى التثبيت والإيضاح فتأتى بمشبه حسى قريب التصور، يزيد

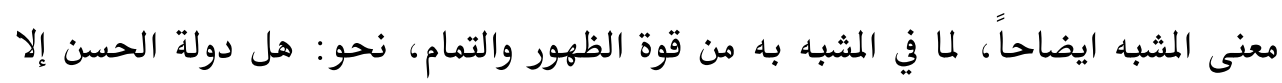
كدولة الزَّهرَ، وهل عمر الصِّبا إلا أصيل أو سحر، وكقوله : إن القلوبَ إذا تنافر وُدُّها مثل فئل الزجاجة كسرها لا يُجبر (شبه تنافر القلوب، بكسر الزجاجة، تثبيتا لتعذر عودة القلوب إلون إلى ما كانت عليه من الأنس والمودَّة)

(0) أو بيان إمكان وجود المشبه، بحيث يبدو غريباً يُستبعد حدُوثه والمشبه به يزيل غرابته ، ويُبين أنه ممكنُ الحصول، كقوله : فان تفق الأنام وأنت منهم فان المسك بعض دُّ دم الغزال

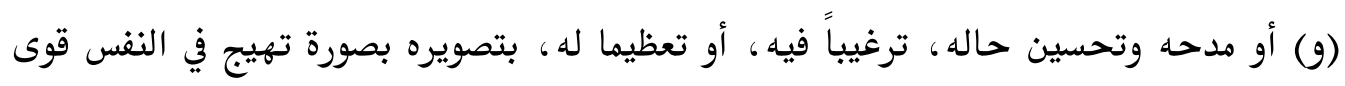

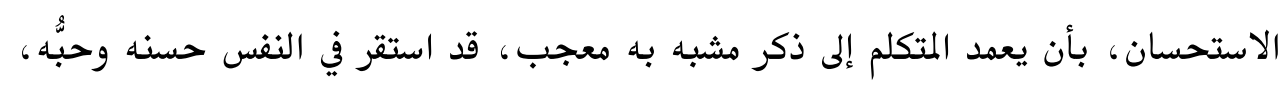
فيصور المشبه بصورته، كقوله : وزاد بك الحسن البديع نضارة كأنك في وجه الملاحة خال ونحو: كأنك شمس والملوك كواكب إذا طلعت لم يبد منهن كوكب وكقوله : سبقت إليك من الحدائق وردة وأتتك قبل أوانها تطفيلا طمعت بلثمك إذ رأتك فجمَّعت فمها إليك

\section{A Jamiy, Jurnal Bahasa dan Sastra Arab Volume 07, No. 1, Juni 2018}


كطالب تقبيلا وكقوله: له خال على صفحات خد كنقطة عنبر في صحن مرمر والحاظ كاسياف تُنادي على عاصي الهوى الله أكبر

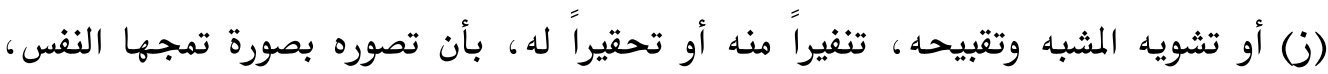
ويشمئز منها الطبع، كقوله : وإذا أشار محدثاً فكأنه قرد يقهقهُ أو عجوزٌ تلطم وكقوله : وترى ناملها دبت على مزمارها كخنافس دبت على أوتار. أو استطرافه (أي عده طريفاً حديثاً) بحيث يجىء المشبه به طريفاً، غير مألوفٍ للذهن؟ ا. و أرد الكاتب أن يكتب هذه البحث العلمية تشبيه المرسل ومضمون معانيها في السورة الرّعد و ابراهيم "الدراسة تحليلة مقارنة ץ) فوائدة التشبيه المرسل في سورة الرّعد وسورة ابرايم في سورة الرّعد

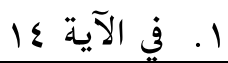

\begin{tabular}{|c|c|}
\hline فائدة & الآيات \\
\hline تقرير حال المشبه & 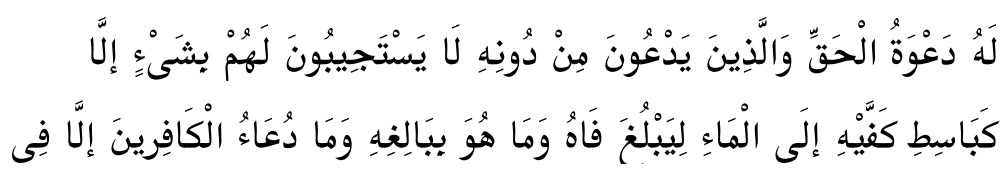 \\
\hline
\end{tabular}

تقرير حال المشبه، وتمكينه في ذهن السامع، بابرازها فيما هي فيه أظهر. وذلك تتصور في

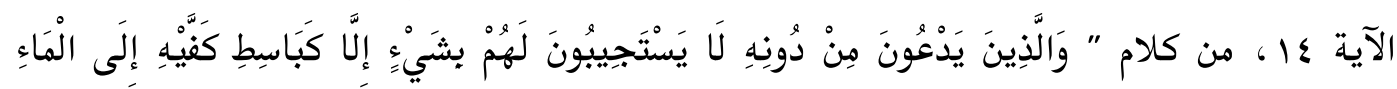

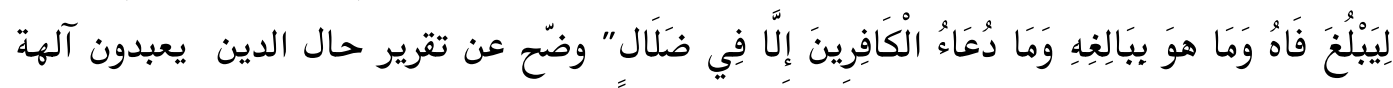

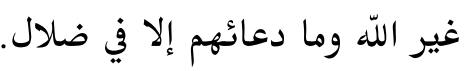
r. - ب في الآية 17 من في سورة الرّعد

فائدة

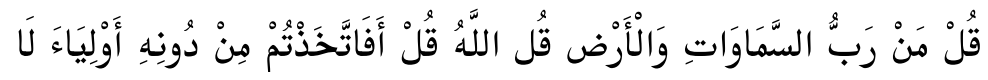

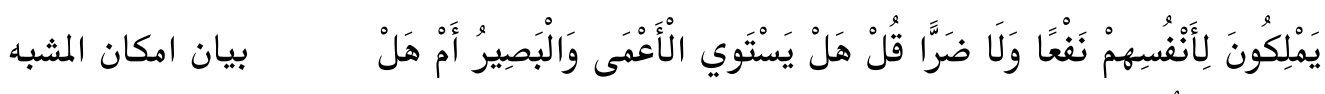

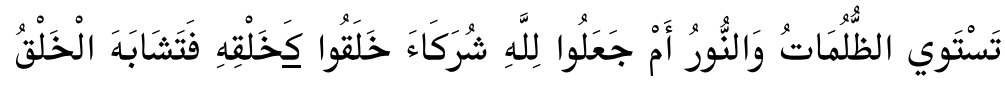

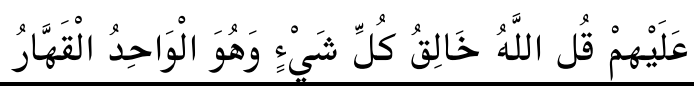

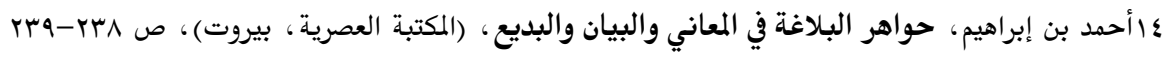

\section{'A Jamiy, Jurnal Bahasa dan Sastra Arab Volume 07, No. 1, Juni 2018}


بيانُ إمكان حاله - وذلك حين يُسند إليه أمر مستغرب لا تزول غرابته إلا بذكر شبيه له ، معروفٍ واضح مُسَّلم به، ، ليثبت في ذهن السامع ويتقرّ وذلك تتصور في الآية 17.

\begin{tabular}{|c|c|}
\hline فائدة & الآيات \\
\hline بيان مقدار حال المشبه & 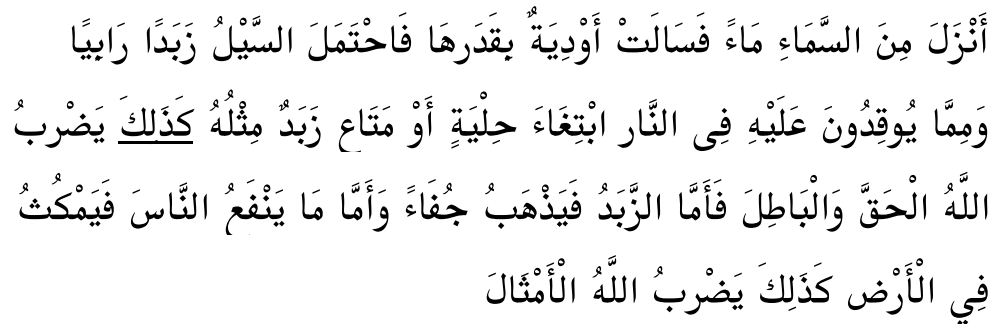 \\
\hline
\end{tabular}

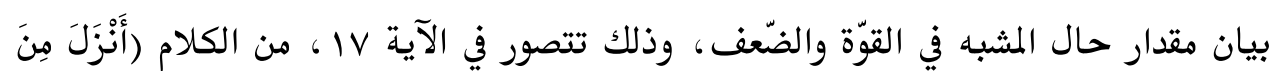

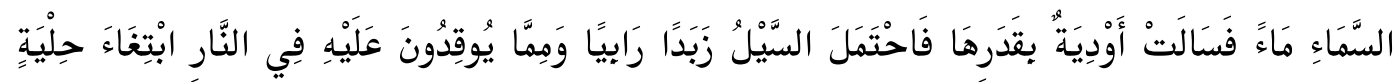

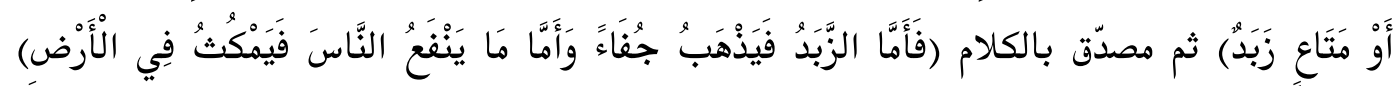
هذة بيان مقدار حال المشبه أي الْحَقَّ وَالْبَاطِلَ. ع. في الآية 19 من في سورة الرّعد

\begin{tabular}{|c|c|}
\hline فائدة & الآيات \\
\hline
\end{tabular}

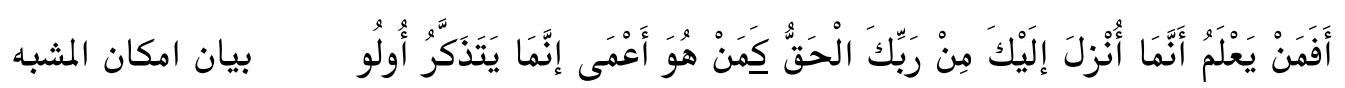
انْأَبَبَاب

بيانُ إمكان حاله - وذلك حين يُسند إليه أمر مستغرب لا تزول غرابته إلا بذكر شبيه له،

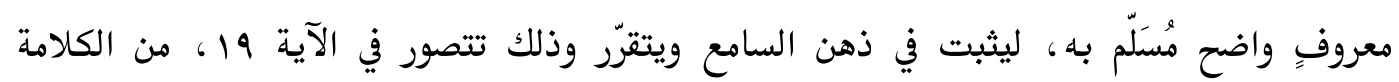

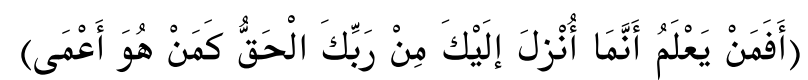

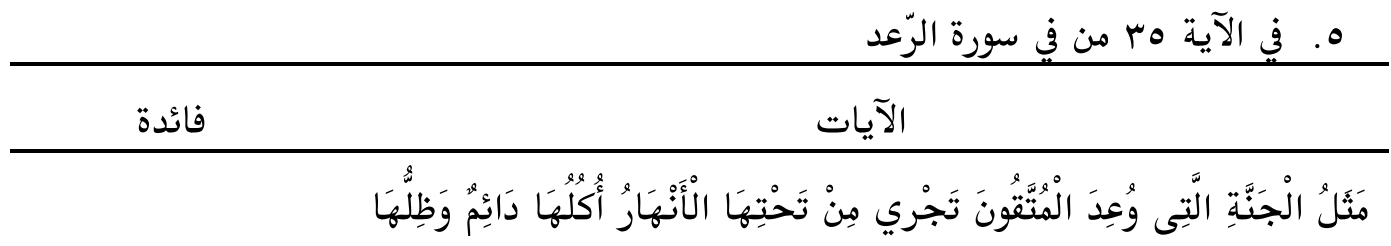

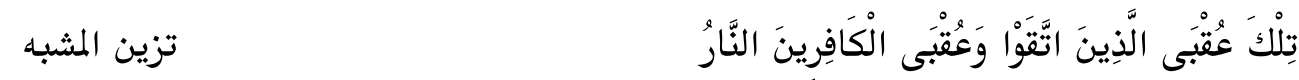

مدحه وتحسين حاله، ترغيباً فيه، أو تعظيما له، بتصويره بصورة تهيج في النفس قوى الاستحسان، بأن يعمد المتكلم إلى ذكر مشبه به معجب، قد استقر في النفس حسنه وحبُّه، فيصور 'A Jamiy, Jurnal Bahasa dan Sastra Arab Volume 07, No. 1, Juni 2018 


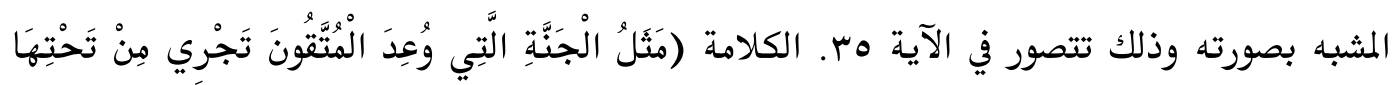

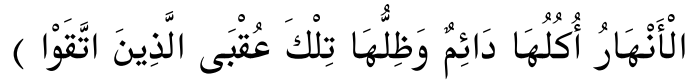

$$
\text { ـ في سورة ابراهيم }
$$

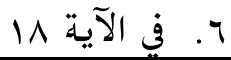

\begin{tabular}{|c|c|}
\hline فائدة & الآيات \\
\hline & 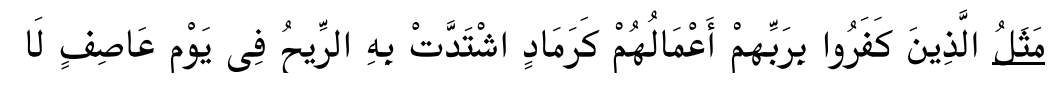 \\
\hline بيان مقدار حال & 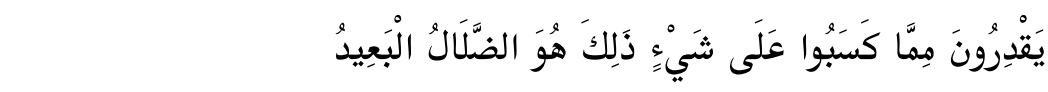 \\
\hline المشبه & \\
\hline
\end{tabular}

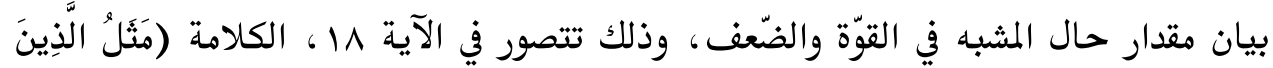

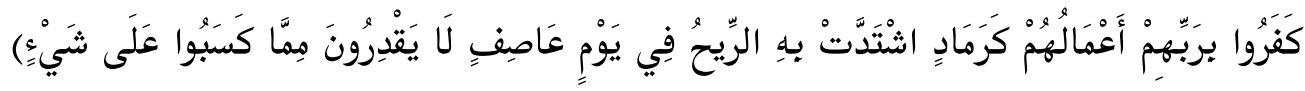

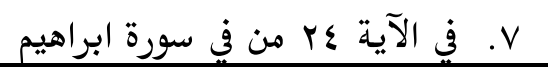

\begin{tabular}{|c|c|}
\hline فائدة & الآيات \\
\hline بيان حاله & 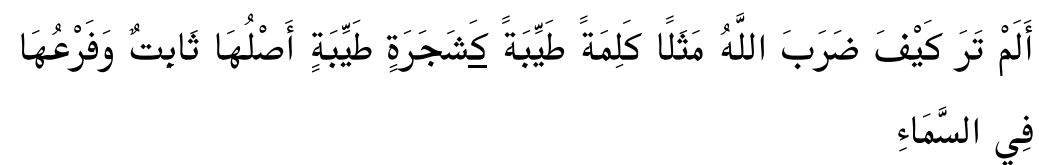 \\
\hline
\end{tabular}

بيان حاله وذلك حينما يكون المشبه مبهماً غير معروف الصفة، التي يُراد إثباتها له قبل

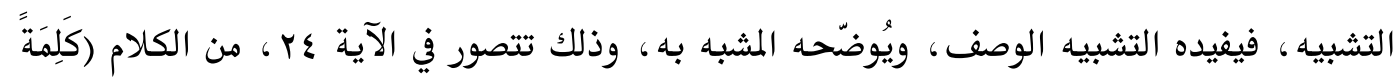

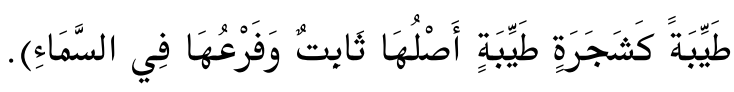

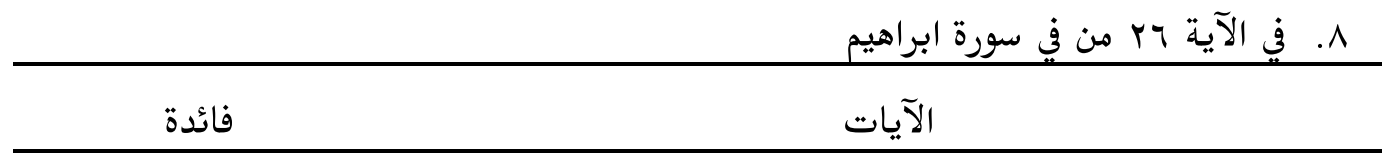

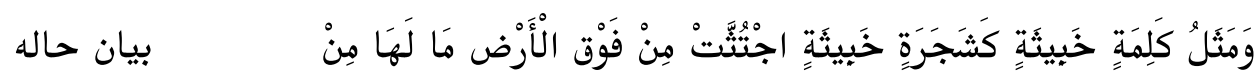

قَرَار

بيان حاله وذلك حينما يكون المشبه مبهماً غير معروف الصفة، التي يُراد إثباتها له قبل

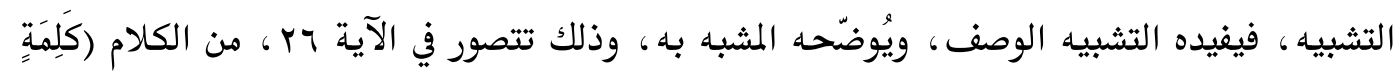

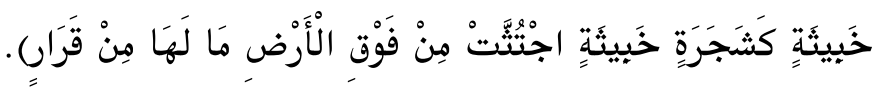

\section{'A Jamiy, Jurnal Bahasa dan Sastra Arab Volume 07, No. 1, Juni 2018}




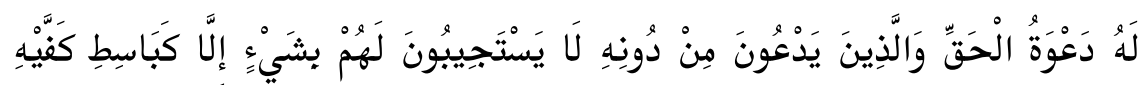

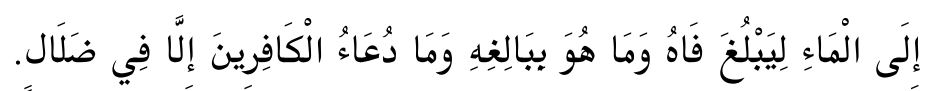

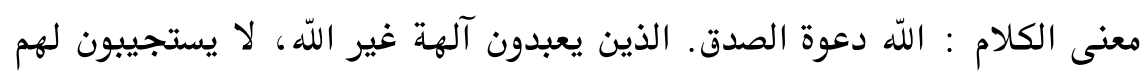

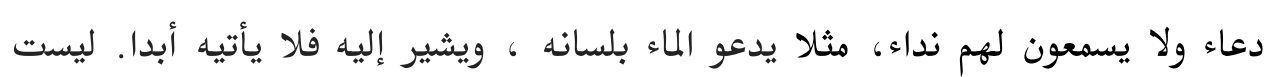
عبادة الكافرين الأصنام إلا في ضلال ، لأنها شرك.

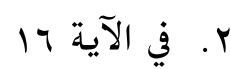

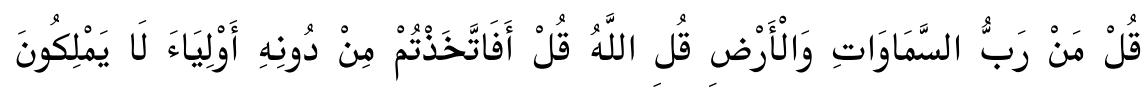

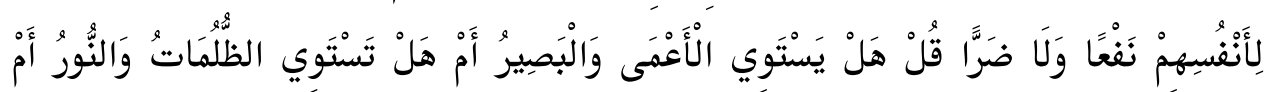

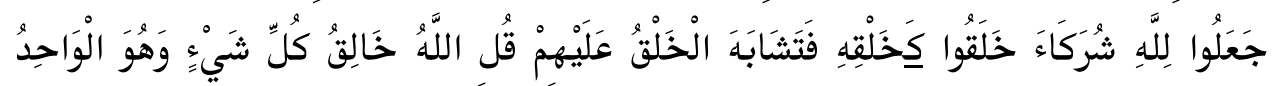
الْقَََّرُ.

معنى الكلام : قل من رب السماوات والأرض ثم أمره أن يقول لهم : هو الله إلزاما للحجة إن لم يقولوا ذلك، وجهلوا من هو. (قل أفاتخذتم من دونه أولياء) هذا يدل على اعترافهم بأن الله هو الخالق وإلا لم يكن للاحتجاج. أجعل هؤلاء المشركون مع اللّ هوله آلهة تناظر الرب وتماثله في الخلق ، فخلقوا كخلقه ، فتشابه الخلق عليهم ، فلا يدرون أنها مخلوقة من مخلوق غيره ؟ أي : ليس الأمر كذلك ، فإنه لا يشابهه شيء ولا يماثله ، ولا ند له ولا عدل له ، ولا وزير له ، ولا ود ولا صاحبة ، تعالى الله عن ذلك علوا كبيرا . وإنما عبد هؤلاء المشركون معه آلهة هم يعترفون أنها مخلوقة له عبيد له ، كما كانوا يقولون في تلبيتهه : لبيك لا شريك لك ، إلا شريكا هو لك ، تملكه وما ملك .

\section{A Jamiy, Jurnal Bahasa dan Sastra Arab Volume 07, No. 1, Juni 2018}




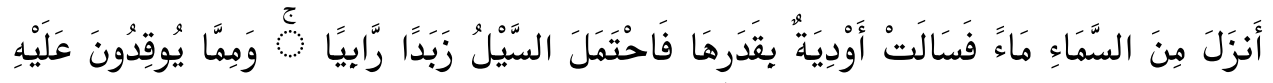

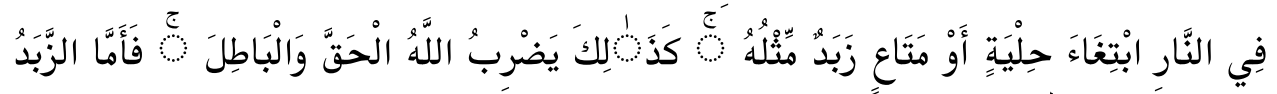

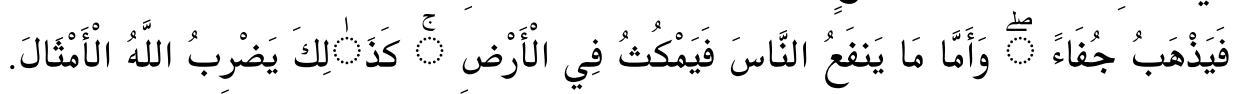

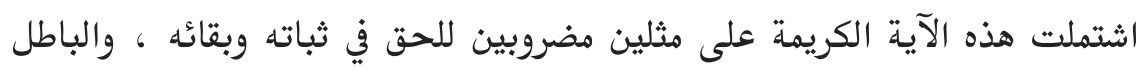

$$
\text { ع. في الآية } 19 .
$$

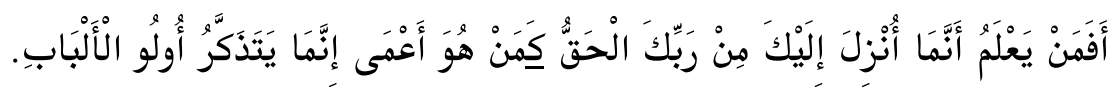

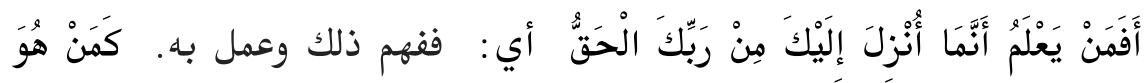

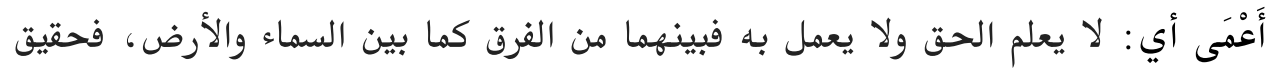

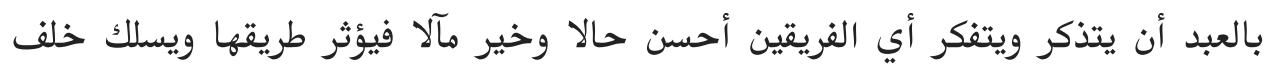

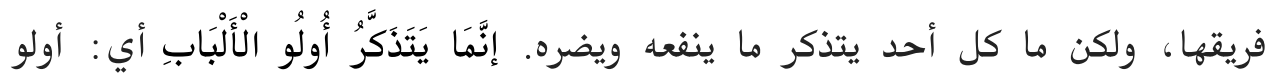

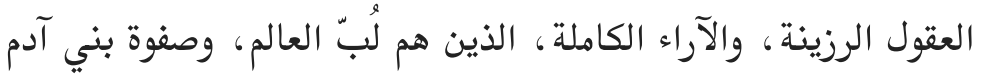

$$
\begin{aligned}
& \text { ه. في الآية هب }
\end{aligned}
$$

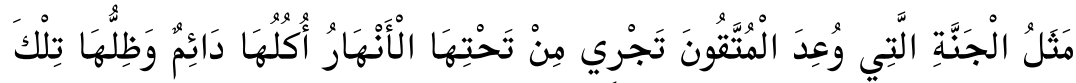

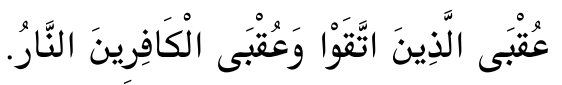

معنى الكلام : صفة الجنة التى وعد اللّ إياها من اتقاه وصان نفسه عن كل مالا

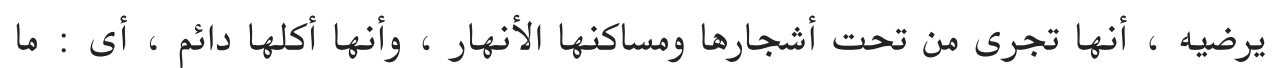

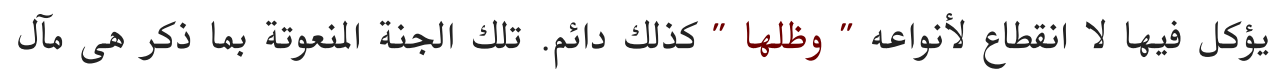

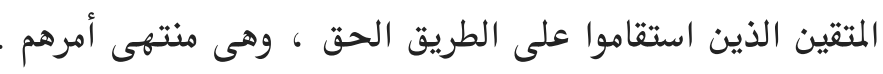

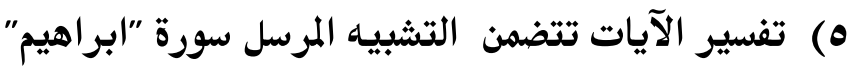

$$
\begin{aligned}
& \text { 1. في الآية 1 1 }
\end{aligned}
$$

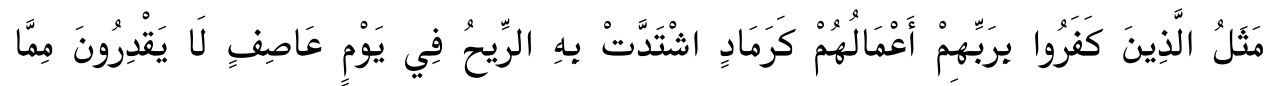

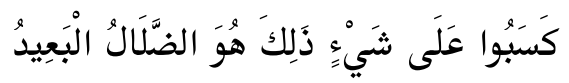

يخبر تعالى عن أعمال الكفار التي عملوها: إما أن المراد بهان الأعمال التهال التي عملوها

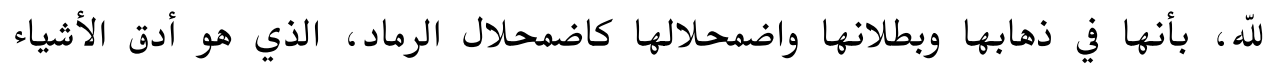

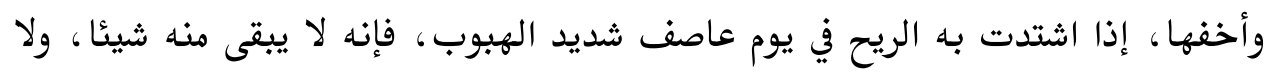

\section{'A Jamiy, Jurnal Bahasa dan Sastra Arab Volume 07, No. 1, Juni 2018}


يقدر منه على شيء يذهب ويضمحل، فكذلك أعمال الكفار (لَ يَقْدِرُونَ مِمَّا كَسَبْوا عَلَى

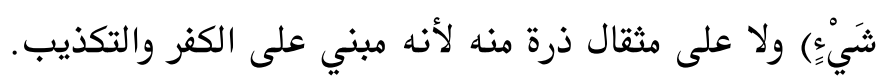

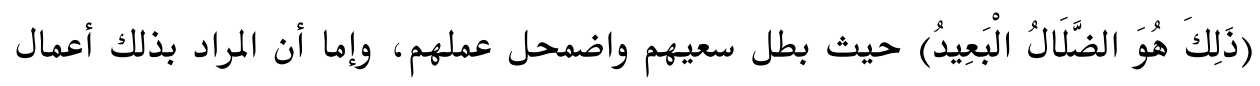

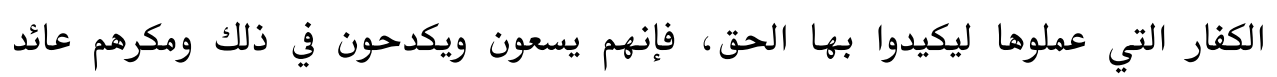
عليهم ولن يضروا الله ورسله وجنده وما معهم من الحق شيئا.

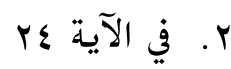

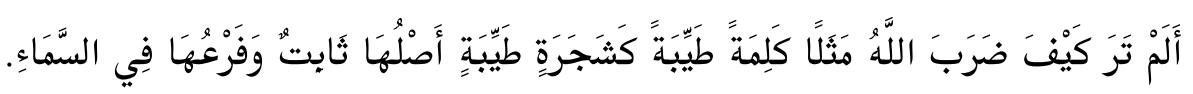

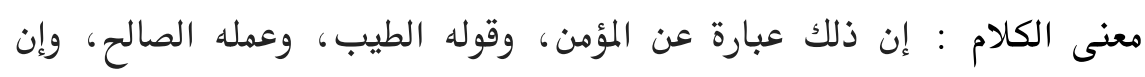

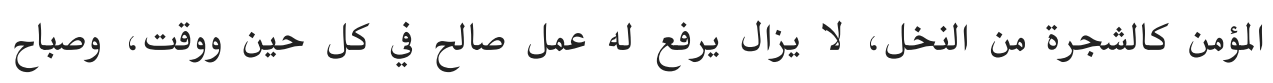

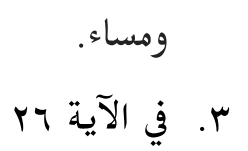

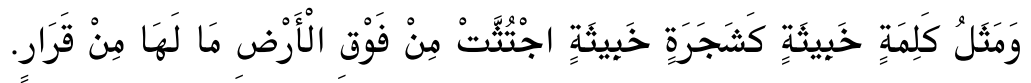

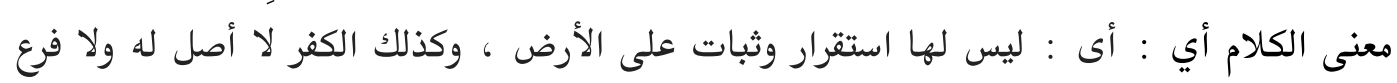

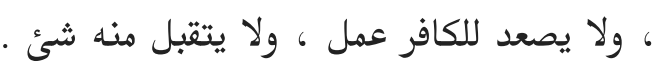

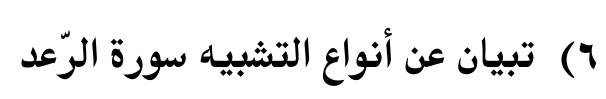

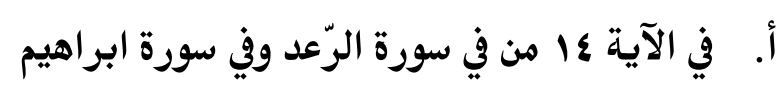

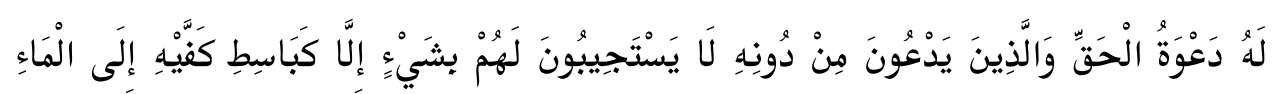

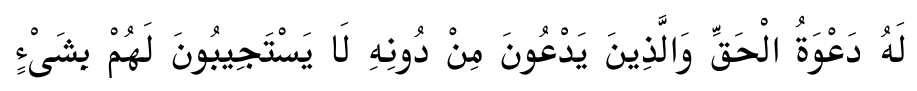
الآيات

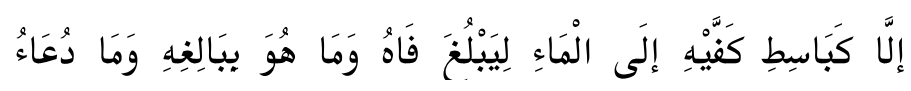

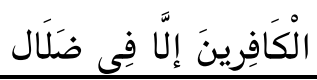

انواع التشبيه (منظور من ثانيا التشبيه جمع هو شبّه لفظ مفرد في لفظ مركّب او مشبه به كثير ثم وحد المشبه. طرفه) تشبيه مفصّل و تشبيه قريب انواع التشبيه (منظور من (من الحال وجه شبّهَ)

انواع التشبيه (منظور من اداة تشبيه مرسل 


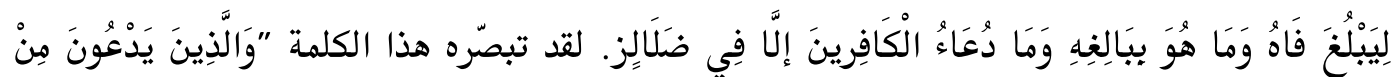

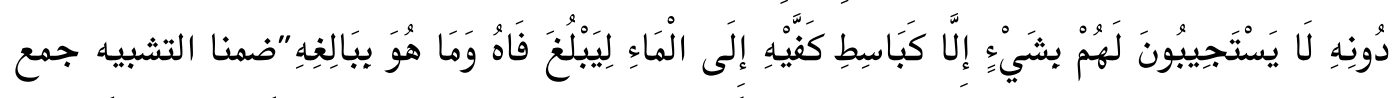

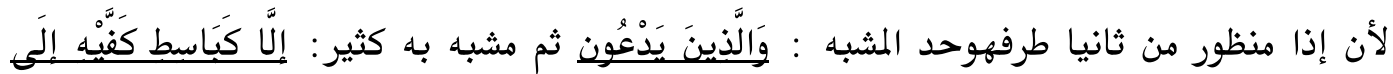

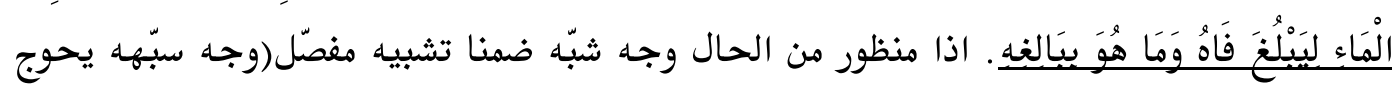
البيان) و تشبيه قريب (الواضح، ليس صعب يبحث عن القربته). ثم منظور من اداة التشبيه اسمه تشبييه مرسل.

$$
\text { ب. في الآية } 19 \text { من في سورة الرّعد }
$$

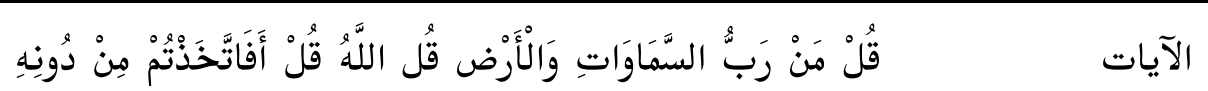

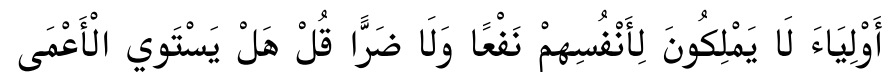

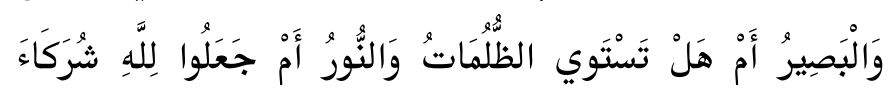

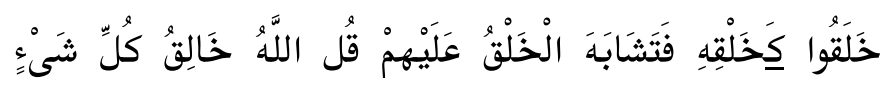

\section{وَهُوَ الْوَاحِدُ الْقَهَّارُ.}

انواع التشبيه (منظور من ثانيا التشبيه مفروق هو شبّه لفظ مركب في لفظ مركب او أجاء

بمشبه و مشبه به ثم المشبه و مشبه به ايض.

طرفه

تشبيه مفصّل و تشبيه قريب

انواع التشبيه (منظور من الحال

وجـه شبّه (

تشبييه مرسل

انواع التشبيه (منظور من اداة

التشبيهه)

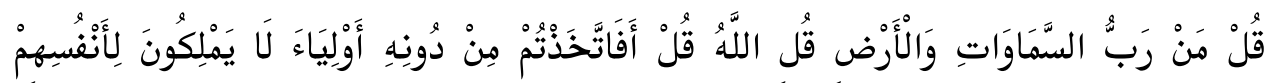

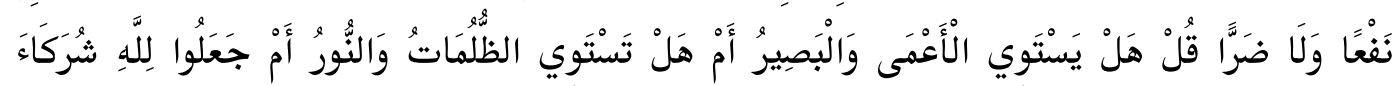

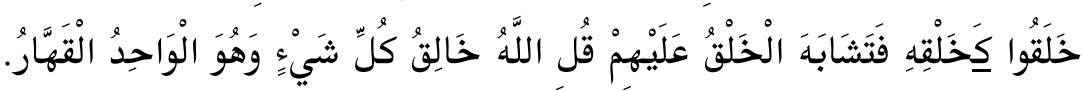

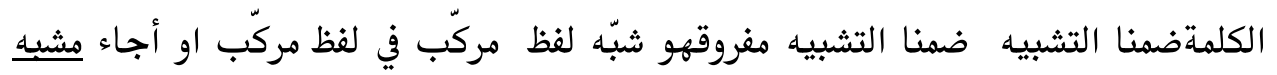

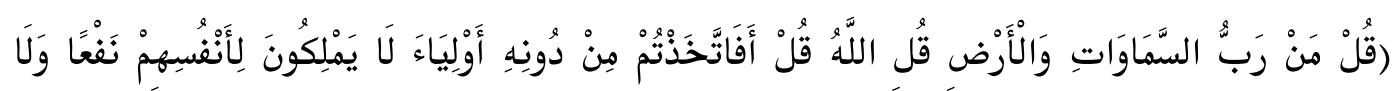

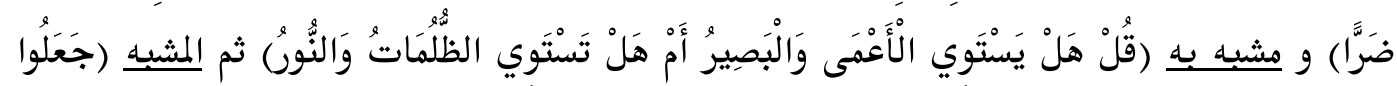

\section{'A Jamiy, Jurnal Bahasa dan Sastra Arab Volume 07, No. 1, Juni 2018}




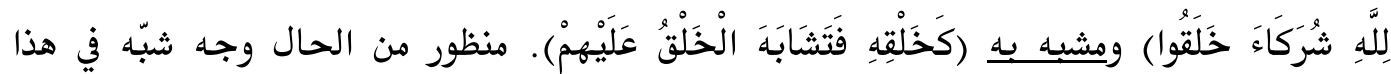
الكلمة هو تشبيه مفصّل(وجه سبّهه يحوج البيان) و تشبيه قريب (الواضح، ليس صعب يبحث عن القربته). ثم مذظور من اداة التشبيه اسمه تشبيه مرسل. ت. في الآية VI من في سورة الرّعد

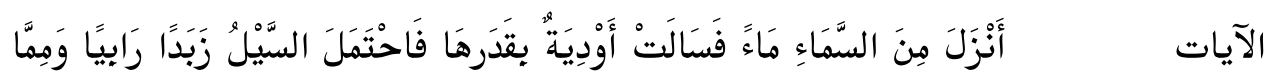

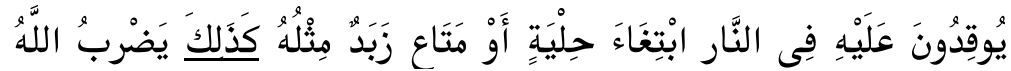

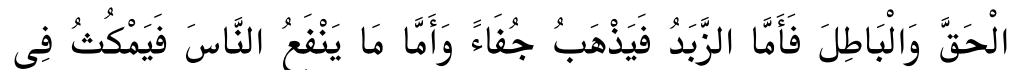

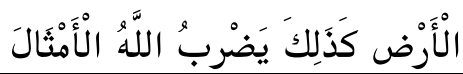

انواع التشبيه (منظور من التشبيه ملفوف هو أجاء بضع مشبه و انتفع العطف ثم مشيه به كذلك

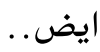
ثانيا طرفه) انواع التشبيه (منظور من تشبيه جلي وقريب الحال وجه شبّه ) انواع التشبيه (منظور من تشبيه مرسل

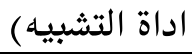

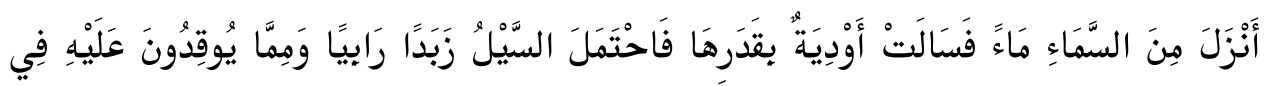

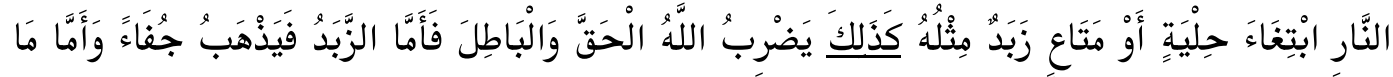

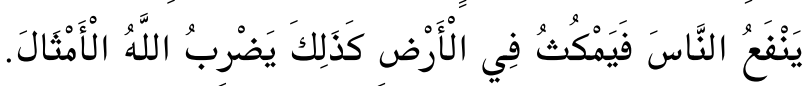

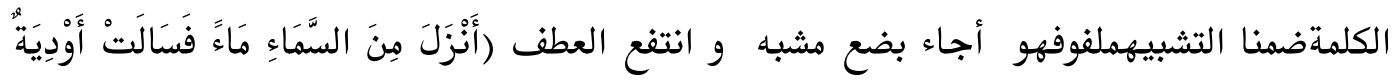

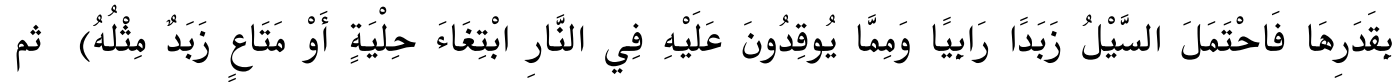

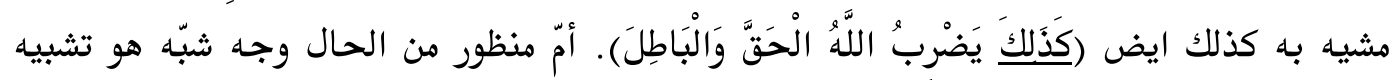
جلي :وجهه سهل في فهم) وقريب ((الواضح، ليس صعب يبحث عن القربته). ثم منظور من اداة التشبيه الكلمة تشبيه مرسل.

\section{'A Jamiy, Jurnal Bahasa dan Sastra Arab Volume 07, No. 1, Juni 2018}


ث. ـ في الآية 19 من في سورة الرّعد

\begin{tabular}{|c|c|}
\hline 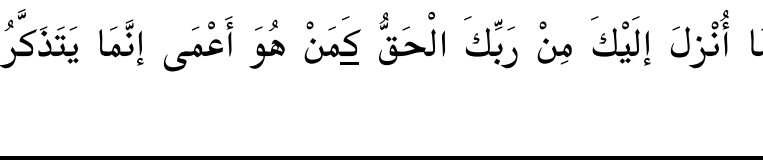 & الآيات \\
\hline التشبيه تسويه هو مشبّه كثير ثم مشبه به و واحد فقط. & $\begin{array}{l}\text { انواع التشبيه (منظور من ثانيا طرفه) } \\
\text { ثنانه }\end{array}$ \\
\hline تشبيه مفصّل و تشبيه قريب & انواع التشبيه (منظور من الحال وجه شبّه) \\
\hline ت تشبيه مرسل & $\begin{array}{l}\text { انواع التشبيه (منظور من اداة } \\
\text { التشبيه) }\end{array}$ \\
\hline
\end{tabular}

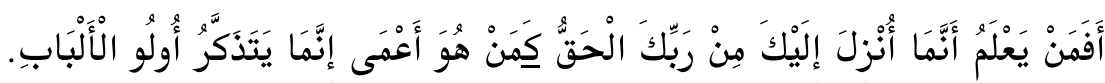

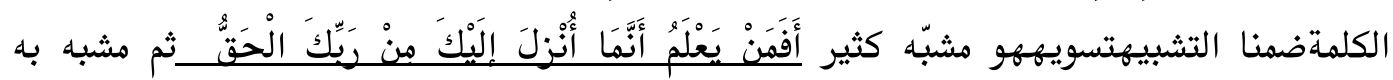

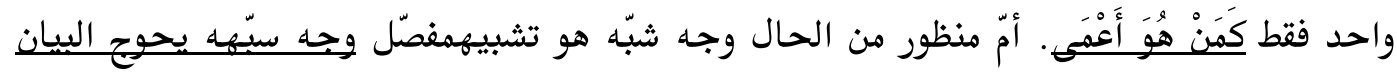
و تشبيه قريب الواضح، ليس صعب يبحث عن القريته. ثم منظور من اداة التشبيه اسمه تشبيه مرسل. ج. في الآية هـ من في سورة الرّعد

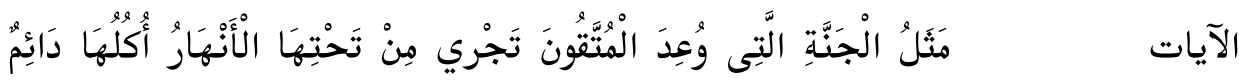

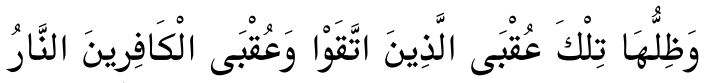

انواع التشبيه (منظور من التشبيه جمع هو شبّه لفظ مفرد في لفظ مركبّ او مشبه به كثير ثم

$$
\begin{aligned}
& \text { ثانيا طرفه) المشبه وحد فقط. } \\
& \text { انواع التشبيه (منظور من تشبيه جلي و تشبيه قريب } \\
& \text { الحال وجه شبّه) } \\
& \text { انواع التشبيه (منظور من اداة تشبيه مرسل }
\end{aligned}
$$

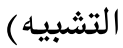

'A Jamiy, Jurnal Bahasa dan Sastra Arab

Volume 07, No. 1, Juni 2018 


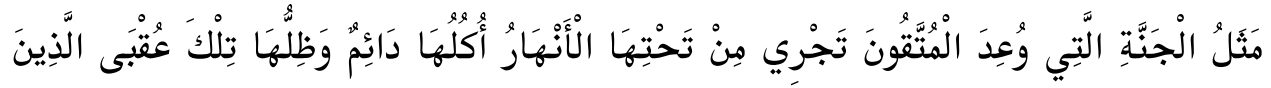

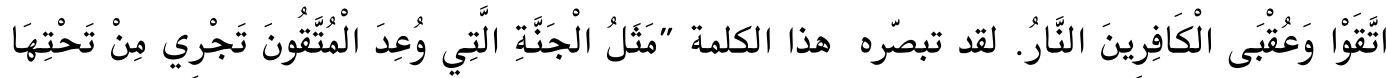

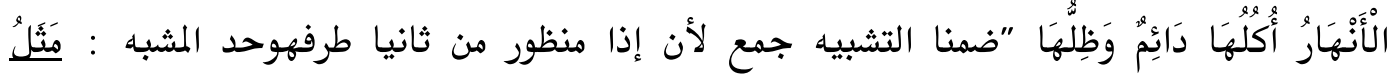

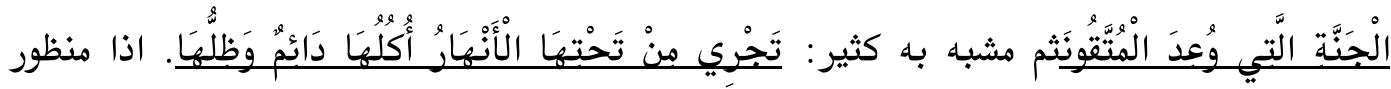

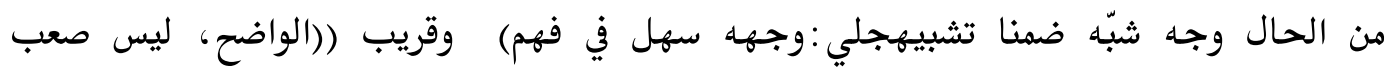
يبحث عن القربته). ثم منظور من اداة التشبيه الكلمة تشبيه مرسل. ح. في الآية 1 ا من في سورة ابراهيم

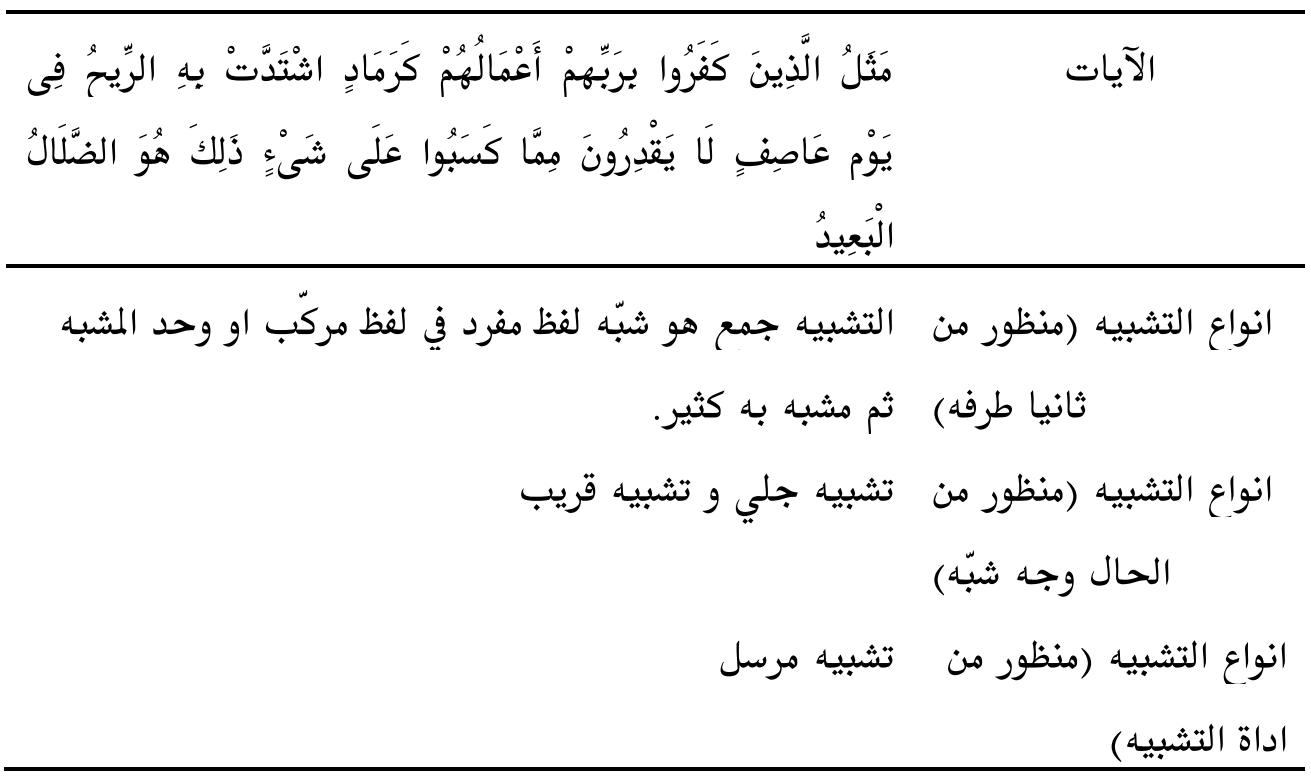

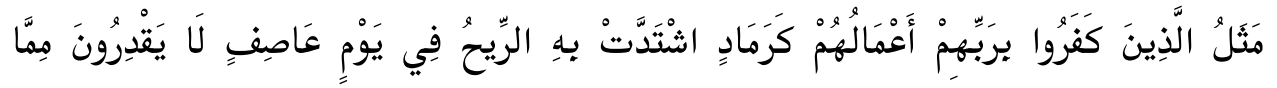

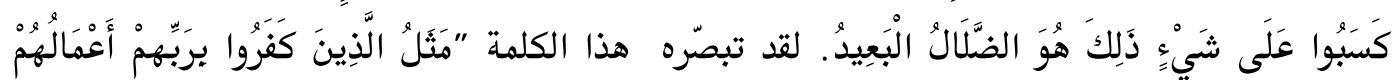

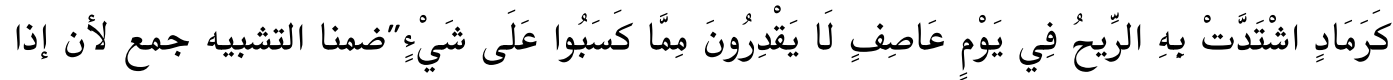

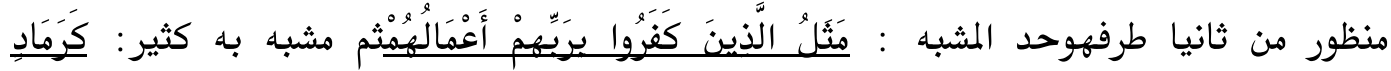

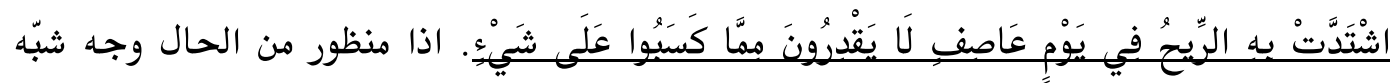
ضمنا تشبيه جلي:وجهه سهل في فهم) وقريب (الواضح، ليس صعب يبحث عن القربته). ثم منظور من اداة التشبيه الكلمة تشبيه مرسل.

\section{'A Jamiy, Jurnal Bahasa dan Sastra Arab Volume 07, No. 1, Juni 2018}


خ. في الآية عr من في سورة ابراهيم

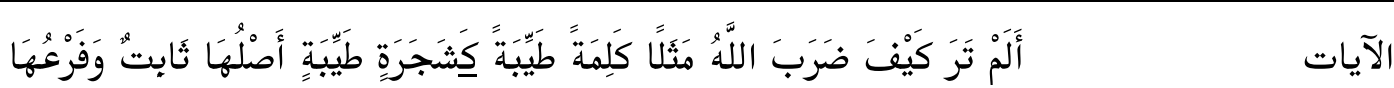

$$
\text { فِي السَّمَاءِ }
$$

التشبيه جمع هو شبّه لفظ مفرد في لفظ مركبّ او وحد المشبه ثم مشبه به

انواع التشبيه (منظور

$$
\text { من من انوانيا طرفه) }
$$

من اداة التشبيهه)

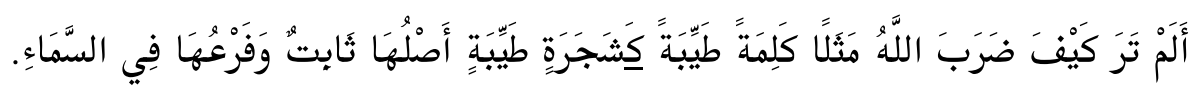

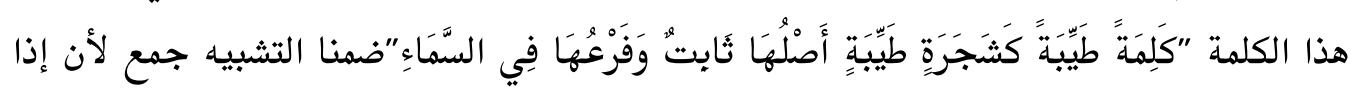

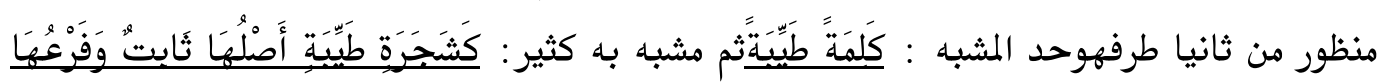
في السَّمَاءء. اذا مذظور من الحال وجه شبّه ضمنا تشبيهجلي :وجهه سهل في فهم وقريب : الواضح، ليس صعب يبحث عن القربته ثم مذظور من اداة التشبيه الكلمة تشبيه مرسل.

$$
\text { د. في الآية جr من في سورة ابراهيم }
$$

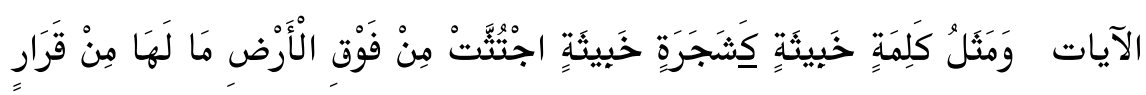

انواع التشبيه (هنظور التشبيه جمع هو شبّه لفظ مفرد في لفظ مركبّ او وحد المشبه ثم مشبه به

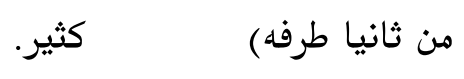

انواع التشبيه (منظور تشبيه مفصّلو تشبيه قريب

$$
\text { من الحال وجه شبّه ) }
$$

$$
\text { انواع التشبيه (منظور تشبيه مرسل }
$$

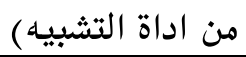

'A Jamiy, Jurnal Bahasa dan Sastra Arab

Volume 07, No. 1, Juni 2018 


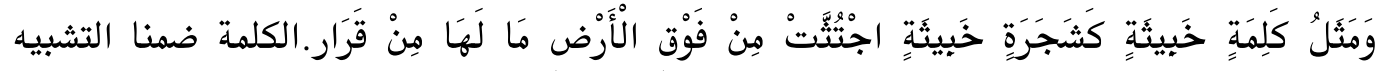

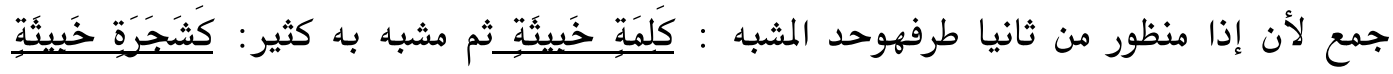

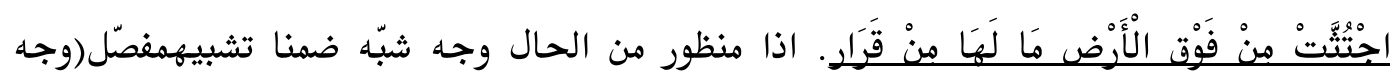
سبّهه يحوج البيان) و تشبيه قريب (الواضح، ليس صعب يبحث عن القربته). ثم منظور من اداة التشبييه اسمه تشبيه مرسل.

ج. الخلاصة

القراءات جمع قراءةٍ، وهي مصدر الفعل قرأ، يقال : قرأ، يقرأ، قراءةً, وقرآنَا بمعنى تلا.

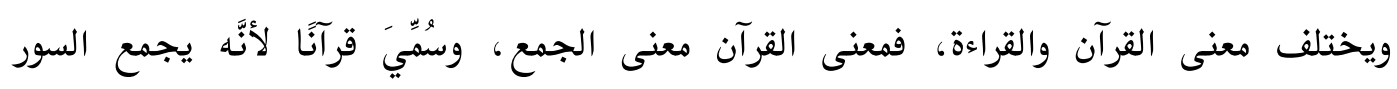
فيضمها، وهو اسم الكتاب الذي أنزل الله على نبيه صلى الله عليه وسلم. أسماء القراء السبعة:

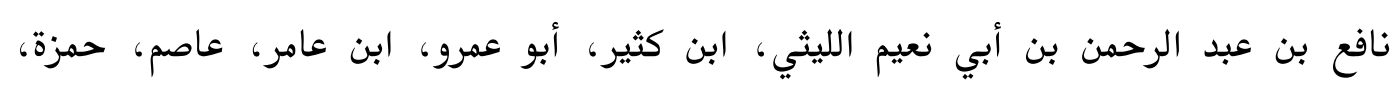

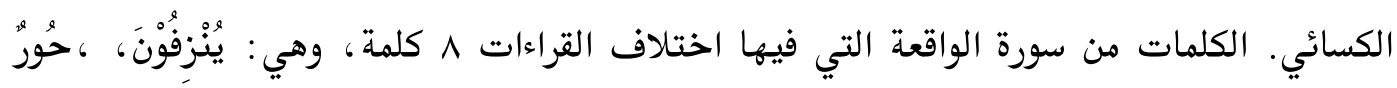

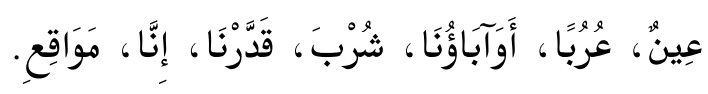

المراجع

القرآن الكريم

علي بن محمد بن سالم، غيث النفع في القراءات السبع، بيروت، دار الكتب العلمية، الطبعة

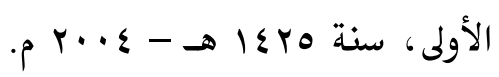

محمد محمد محمد سالم محيسن، القراءات وأثرها في علوم العربية، القاهرة، مكتبة الكليات

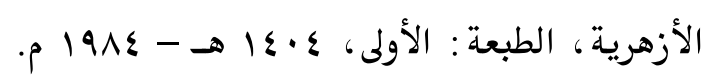

أبي بكر أحمد بن موسى بن مجاهد، السبعة في القراءات، مصر، دار المعارف، الطبعة الثالثة:

$$
\cdot \text { p } 9 \wedge \Lambda=-81 \varepsilon \cdot \Lambda
$$

محمد محمد محمد سالم محيسن، الهادي شرح طيبة النشر في القراءات العشر، بيروت، دار

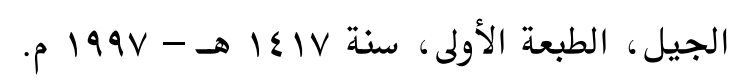

محمد بن أحمد بن الأزهري الهروي، معاني القراءات للأزهري، المملكة العربية السعودية، مركز

'A Jamiy, Jurnal Bahasa dan Sastra Arab

Volume 07, No. 1, Juni 2018 
البحوث في كلية الآداب - جامعة الملك سعود، الطبعة الأولى، سنة ب|ع| هـ - 1991 م.

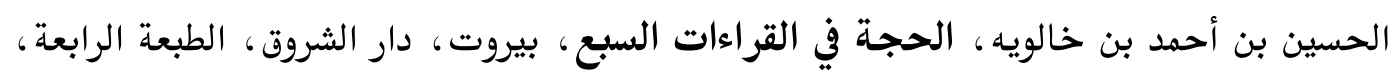

$$
\text { سنة الم؟ا هـ. }
$$

عبد الرحمن بن محمد، حجة القراءات، بيروت، دار الرسالة، الطبعة الخامسة، سنة هاء1

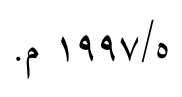

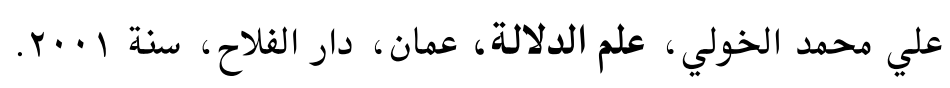

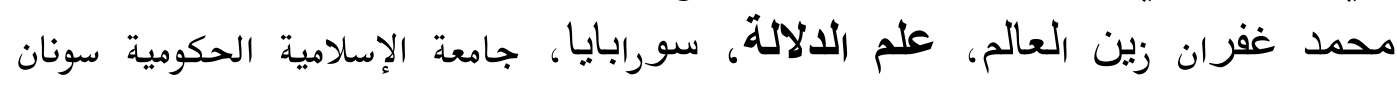

$$
\text { أمبيل، سنة } 1997 \text { م. }
$$

أبو داود سليمان بن داود بن الجارود الطيالسي البصرى، هسند أبي داود الطيالسي، مصر، دار

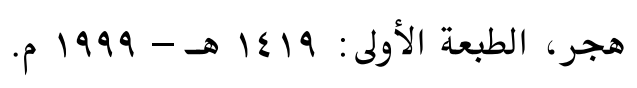

